\title{
$\beta$-Blockers Reduced the Target Lesion Revascularization After Percutaneous Coronary Intervention Using an Everolimus-eluting Stent
}

\author{
TATSUYA FUJINAMI ${ }^{1,2}$, TAKASHI ASHIKAGA ${ }^{3}$, KATSUYUKI HOSHINA $^{4}$, TARO SASAOKA ${ }^{5}$, \\ KEN KURIHARA ${ }^{6}$, SHUNJI YOSHIKAWA ${ }^{7}$, HIROSHI INAGAKI $^{8}$ and TETSUO SASANO $^{1}$ \\ ${ }^{1}$ Department of Cardiovascular Medicine, Tokyo Medical and Dental University, Tokyo, Japan; \\ ${ }^{2}$ Department of Cardiology, Toshima Hospital, Tokyo, Japan; \\ ${ }^{3}$ Department of Cardiology, Musashino Red Cross Hospital, Tokyo, Japan; \\ ${ }^{4}$ Department of Vascular Surgery, The University of Tokyo, Tokyo, Japan; \\ ${ }^{5}$ Kamiigusa Clinic, Tokyo, Japan; \\ ${ }^{6}$ Department of Cardiology, Ome Municipal General Hospital, Tokyo, Japan; \\ ${ }^{7}$ Department of Cardiology, Tokyo Yamate Medical Center, Tokyo, Japan; \\ ${ }^{8}$ Department of Cardiology, Soka Municipal Hospital, Saitama, Japan
}

\begin{abstract}
Background/Aim: The effect of $\beta$-adrenergic blockers on everolimus-eluting stent (EES) implantation is unknown. We aimed to investigate how $\beta$-blockers affect the outcomes of EES by using the Tokyo-MD PCI registry data and analyse real-world data in this drug-eluting stent era in Japan. Patients and Methods: We selected 1,899 patients who underwent EES implantation. We compared patients with $\beta$-blocker administration versus those without, at follow-up regarding the incidence rate of ischemia-driven target lesion revascularization (ID-TLR), all-cause death, cardiac death, acute myocardial infarction (AMI), and stent thrombosis (ST). Results: Patients in the $\beta$-blocker group had higher coronary risks than those in the non- $\beta$-blocker group. Although no significant difference was observed in the five-year incidence of all-cause death, cardiac death, $A M I$, and ST between the two groups, the incidence of IDTLR was significantly lower in the $\beta$-blocker group $14.5 \%$ vs. $6.6 \% ; p=0.04)$. $\beta$-Blocker administration (hazard ratio $=0.61 ; p=0.016)$ was negatively associated with IDTLR via multivariate analysis. Conclusion: $\beta$-Blocker
\end{abstract}

This article is freely accessible online.

Correspondence to: Tetsuo Sasano, Department of Cardiovascular Medicine, Tokyo Medical and Dental University, Yushima 1-5-45, Bunkyo City, Tokyo 113-8519, Japan. Tel: +81 358035231, e-mail: sasano.bi@tmd.ac.jp

Key Words: Everolimus-eluting stent, $\beta$-blocker, interventional cardiology, target lesion revascularization, coronary artery lesion. administration reduced ID-TLR after percutaneous coronary intervention using an EES despite the greater comorbid risks and more severe disease lesions.

In the history of percutaneous coronary intervention (PCI) with coronary stenting for the treatment of coronary artery disease (CAD), stent restenosis has always been a major problem (1-3). Drug-eluting stents (DES) first emerged in the 2000s with great impact on improving clinical outcomes including a dramatic reduction in stent restenosis rate compared to bare metal stents (BMS) $(4,5)$. However, delayed healing, which includes delayed reendothelialization, continuous chronic inflammation, and fibrin deposition, was revealed to be the next problem. The outcomes of DES were improved by changing the polymer and stent design. Everolimus-eluting stents (EES) are one of the most widely used devices worldwide and are generally accepted and favored by Japanese cardiologists with longterm excellent performance within the recent decade $(6,7)$.

$\beta$-Adrenergic blockers ( $\beta$-blockers) are predominantly used to manage abnormal heart rhythms and to protect the heart from myocardial infarction after an initial heart attack event in what has been termed as "secondary prevention." They are also widely used for treating hypertension and are recommended as first-line drug for single-drug use in the Japanese guidelines; however, they are not recommended for use in combination with other hypertensive drugs. Therefore, the proportion of $\beta$-blockers used in Japan is lower than that of calcium channel blockers (CCBs), angiotensin II receptor blockers (ARBs), and angiotensin-converting enzyme inhibitors (ACEIs). 
The Tokyo-MD PCI study was a physician-initiated, multicenter, observational study that was conducted to evaluate real-world data of Japanese patients who underwent EES. Current guidelines for the treatment of CAD recommend daily oral administration of $\beta$-blockers as long as there are no contraindications (8-10). $\beta$-Blockers were reported to have a secondary effect in reducing the incidence of restenosis after PCI (11), which might be another reason for prescribing $\beta$-blockers in this cohort.

Herein, we investigated how $\beta$-blockers affected the outcomes of EES using the Tokyo-MD PCI registry data and analyzed real-world data in this DES era in Japan.

\section{Patients and Methods}

Study population. The Tokyo-MD PCI study consisted of data from 1,925 patients with 2,330 lesions undergoing EES [XIENCE V (Abbott Vascular, Santa Clara, CA, USA), or Promus stent (Boston Scientific, Natick, MA, USA)] implantation across 22 institutions between January 2010 and December 2011. There were no exclusion criteria for patient selection. Patient demographic and other clinical characteristics were retrospectively collected from hospital charts or clinical databases. Adverse events were searched for up to five years after EES implantation. This study was approved by the institutional ethical review board at Tokyo Medical and Dental University and was conducted according to the Ethical Guidelines for Epidemiological Research. We published all relevant details of this study after obtaining informed consent.

Definition of terms. Current smoking, hypertension, diabetes mellitus, dyslipidemia, chronic kidney disease (CKD) with or without hemodialysis, peripheral artery disease, prior myocardial infarction (MI), prior PCI, prior coronary artery bypass grafting, and family history of CAD were regarded as present when these diagnoses were recorded in hospital charts. Obesity was defined as having a body mass index of $\geq 25 \mathrm{~kg} / \mathrm{m}^{2}$. Acute MI (AMI) was defined as ischemic symptoms, followed by a typical rise in concentrations of troponin above the 99th percentile upper reference limit or as an increase in creatine kinase (CK) or CK-MB to more than double the normal value. Acute coronary syndrome (ACS) included ST-segment elevation MI (STEMI), non-STEMI, and unstable angina pectoris. Cardiogenic shock was defined as having a systolic pressure $\leq 90 \mathrm{mmHg}$ lasting over $30 \mathrm{~min}$ due to cardiac dysfunction in the presence of adequate intravascular volume and left ventricular filling pressure. Left ventricular systolic dysfunction was defined as having a left ventricular ejection fraction (EF) $\leq 35 \%$ on contrast left ventriculography or echocardiography during the hospital stay. All lesion characteristics were diagnosed by physicians within each hospital based on coronary angiograms and imaging devices, such as intravascular ultrasound and optical coherence tomography. Lesion type was defined according to the American College of Cardiology/American Heart Association (ACC/AHA) classification.

All deaths were regarded as cardiac deaths unless unequivocal non-cardiac causes could be identified. Stent thrombosis (ST) was defined according to the Academic Research Consortium definition. Target lesion revascularization (TLR) was defined as revascularization post-stenting within the stent or within the $5-\mathrm{mm}$ borders adjacent to the stent. Ischemia-driven TLR (ID-TLR) was defined as revascularization of the target lesion based on clinical features of ischemia.

Statistical methods. Normally distributed continuous variables were presented as mean \pm standard deviation (SD) and were compared using the Student's $t$-test. Non-normally distributed variables were presented as the median and interquartile range (IQR) and were compared using the Mann-Whitney $U$-test. Categorical data were presented as percentages. Comparisons of proportions were analyzed using the chi-square test or Fischer's exact test if the sample size was small. Cumulative incidence of clinical events was estimated by the Kaplan-Meier method, and differences were assessed using the log-rank test. The incidence of ID-TLR was analyzed per lesion. The Cox proportional hazard model was used to assess the covariates with $\beta$-blockers for IDTLR. Univariate analysis was performed for each of the variables listed in Table I and Table II. The frequency of CKD with hemodialysis was excluded because it was included in the CKD frequency. Multivariate analysis was performed for variables with $p<0.05$. Hazard ratios (HRs) were reported with corresponding 95\% confidence intervals. All analyses were performed using $\mathrm{JMP}^{\circledR} 10.0$ (SAS Institute Inc., Cary, NC, USA). All reported $p$ values were two-sided and $p<0.05$ was regarded as statistically significant.

\section{Results}

Baseline characteristics. Among the 1,925 patients who underwent PCI with EES from the Tokyo-MD PCI study, we were able to analyze data from 1,899 patients after excluding patients whose data regarding $\beta$-blocker use was missing. By the time of their last follow-up, a total of 918 patients received a $\beta$-blocker prescription ( $\beta$-blocker group, $48.3 \%$ ) and 981 patients did not (non- $\beta$-blocker group, $51.7 \%$ ). Patients in the $\beta$-blocker group had a higher frequency of hypertension, CKD with hemodialysis, ACS, left ventricular systolic dysfunction, prior MI, and multivessel disease. Almost all patients were on aspirin $(\beta$ blocker group, 99.7\% vs. non- $\beta$-blocker group, 99.6\%; $p=0.771)$ and thienopyridine $(98.4 \%$ vs. $9.48 \%$; $p=0.996)$. The percentage of patients on anticoagulant agents, statins, ACEIs, and ARBs was significantly higher in the $\beta$-blocker group (Table I).

Lesion and procedural characteristics. A total of 1,133 lesions in the $\beta$-blocker group and 1,172 lesions in the non$\beta$-blocker group were analyzed. In the $\beta$-blocker group, there was a greater percentage of left main coronary artery lesions, ostial lesions, and ACC/AHA classification type $\mathrm{B} 2 / \mathrm{C}$ lesions. Furthermore, in the $\beta$-blocker group, the number of stents used, total length of stent, and patients using the $2.5 \mathrm{~mm}$ diameter stent was higher than in the non$\beta$-blocker group. In both groups, imaging devices were used at high rates for stent placement (94.5\% vs. 93.8\%; $p=0.439$ ) (Table II). 
Table I. Clinical Characteristics of included patients.

\begin{tabular}{|c|c|c|c|}
\hline & $\begin{array}{l}\beta \text { Group } \\
(\mathrm{n}=918)\end{array}$ & $\begin{array}{l}\text { Non- } \beta \text { group } \\
\quad(n=981)\end{array}$ & $p$-Value \\
\hline \multicolumn{4}{|l|}{ Patient background } \\
\hline Age (years) & $70.1 \pm 10.1$ & $69.7 \pm 9.6$ & 0.3201 \\
\hline Male & $686(74.7 \%)$ & $720(73.4 \%)$ & 0.5078 \\
\hline Obesity $\left(\mathrm{BMI} \geq 25 \mathrm{~kg} / \mathrm{m}^{2}\right)$ & $239(28.6 \%)$ & $233(26.5 \%)$ & 0.3744 \\
\hline $\begin{array}{l}\text { Family history of } \\
\text { coronary artery disease }\end{array}$ & $94(11.7 \%)$ & $64(7.8 \%)$ & 0.0075 \\
\hline Current smoking & $192(20.9 \%)$ & $181(18.5 \%)$ & 0.1767 \\
\hline Hypertension & $710(77.3 \%)$ & $681(69.4 \%)$ & $<0.001$ \\
\hline Diabetes mellitus & $392(42.7 \%)$ & $396(40.4 \%)$ & 0.3022 \\
\hline Dyslipidemia & $809(88.1 \%)$ & $749(76.4 \%)$ & $<0.001$ \\
\hline Chronic kidney disease & $232(25.3 \%)$ & $224(22.8 \%)$ & 0.2138 \\
\hline With hemodialysis & $36(3.9 \%)$ & $90(9.2 \%)$ & $<0.001$ \\
\hline Acute coronary syndrome & $352(38.3 \%)$ & $292(29.8 \%)$ & $<0.001$ \\
\hline Cardiogenic shock & $13(1.4 \%)$ & $20(2.0 \%)$ & 0.2995 \\
\hline $\begin{array}{l}\text { Left ventricular systolic } \\
\text { dysfunction }\end{array}$ & $65(7.1 \%)$ & $42(4.3 \%)$ & 0.0082 \\
\hline Peripheral artery disease & $73(8.0 \%)$ & $117(11.9 \%)$ & 0.0029 \\
\hline History of stroke & $86(9.4 \%)$ & $102(10.0 \%)$ & 0.4529 \\
\hline $\begin{array}{l}\text { History of myocardial } \\
\text { infarction }\end{array}$ & $346(37.7 \%)$ & $230(23.5 \%)$ & $<0.001$ \\
\hline $\begin{array}{l}\text { Previous percutaneous } \\
\text { coronary intervention }\end{array}$ & $350(38.1 \%)$ & $331(33.7 \%)$ & 0.0465 \\
\hline $\begin{array}{l}\text { Previous coronary artery } \\
\text { bypass grafting }\end{array}$ & $63(6.9 \%)$ & $56(5.7 \%)$ & 0.2997 \\
\hline Multivessel disease & $443(48.3 \%)$ & $390(39.8 \%)$ & 0.002 \\
\hline \multicolumn{4}{|l|}{$\begin{array}{l}\text { Antiplatelet therapy } \\
\text { at discharge }\end{array}$} \\
\hline Use of aspirin & $915(99.7 \%)$ & $977(99.6 \%)$ & 0.7711 \\
\hline Use of thienopyridine & $903(98.4 \%)$ & $965(98.4 \%)$ & 0.9959 \\
\hline Clopidogrel & $845(92.1 \%)$ & $908(92.6 \%)$ & 0.6764 \\
\hline Ticlopidine & $57(6.2 \%)$ & $57(5.8 \%)$ & 0.7147 \\
\hline Use of cilostazole & $38(4.1 \%)$ & $28(2.9 \%)$ & 0.1265 \\
\hline $\begin{array}{l}\text { Use of two or more } \\
\text { antiplatelet agents }\end{array}$ & $916(99.8 \%)$ & $978(99.7 \%)$ & 0.7086 \\
\hline \multicolumn{4}{|l|}{$\begin{array}{l}\text { Medication at the last } \\
\text { follow-up }\end{array}$} \\
\hline $\begin{array}{l}\text { Use of one or more } \\
\text { antiplatelet agent (s) }\end{array}$ & $908(98.9 \%)$ & $959(97.8 \%)$ & 0.0510 \\
\hline Use of anticoagulant agent & $132(14.4 \%)$ & $101(10.3 \%)$ & 0.0067 \\
\hline Use of statin & $807(87.9 \%)$ & $699(71.3 \%)$ & $<0.001$ \\
\hline Use of ACEI & $188(20.5 \%)$ & $96(9.8 \%)$ & $<0.001$ \\
\hline Use of ARB & $455(49.6 \%)$ & $397(40.5 \%)$ & $<0.001$ \\
\hline Use of ACEI or ARB & $631(68.7 \%)$ & $484(49.3 \%)$ & $<0.001$ \\
\hline $\begin{array}{l}\text { Temporary discontinuation } \\
\text { of antiplatelet agents }\end{array}$ & $43(4.7 \%)$ & $38(3.9 \%)$ & 0.3824 \\
\hline
\end{tabular}

Variables are mean \pm SD or percentage. BMI: Body mass index; ACEI: angiotensin converting enzyme inhibitor; ARB: angiotensin receptor blocker.

Clinical outcomes. The median follow-up duration was 1,910 days (IQR=1.222-2.193). There was no significant difference between the two groups regarding five-year cumulative incidence of all-cause death $(12.4 \% \mathrm{vs} .13 .5 \%$; $p=0.585)$, cardiac death $(4.8 \%$ vs. $6.0 \% ; p=0.265)$, AMI (3.4\% vs. $4.0 \% ; p=0.516)$, and ST $(3.1 \%$ vs. $3.0 \%$;
Table II. Lesion and procedural characteristics.

\begin{tabular}{|c|c|c|c|}
\hline & $\begin{array}{l}\beta \text { Group } \\
(\mathrm{n}=1,133)\end{array}$ & $\begin{array}{l}\text { Non- } \beta \text { group } \\
(\mathrm{n}=1,172)\end{array}$ & $p$-Value \\
\hline \multicolumn{4}{|l|}{ Lesion characteristics } \\
\hline \multicolumn{4}{|l|}{ Coronary lesion location } \\
\hline $\begin{array}{l}\text { Left anterior descending } \\
\text { coronary artery }\end{array}$ & $527(46.5 \%)$ & $527(44.8 \%)$ & 0.4558 \\
\hline $\begin{array}{l}\text { Left circumflex } \\
\text { coronary artery }\end{array}$ & $242(21.4 \%)$ & $266(22.7 \%)$ & 0.4388 \\
\hline Right coronary artery & $357(31.2 \%)$ & $382(32.6 \%)$ & 0.5770 \\
\hline $\begin{array}{l}\text { Left main coronary } \\
\text { artery }\end{array}$ & $72(6.4 \%)$ & $51(4.4 \%)$ & 0.0324 \\
\hline Bypass graft & $5(0.4 \%)$ & $1(0.1 \%)$ & 0.1185 \\
\hline Ostial lesion & $184(16.2 \%)$ & $148(12.6 \%)$ & 0.0135 \\
\hline Bifurcation lesion & $279(24.6 \%)$ & $271(21.1 \%)$ & 0.3977 \\
\hline Restenosis lesion & $126(11.1 \%)$ & $124(10.6 \%)$ & 0.6764 \\
\hline Chronic total occlusion & $82(7.2 \%)$ & $89(7.6 \%)$ & 0.7441 \\
\hline Severe calcified lesion & $248(21.9 \%)$ & $263(22.4 \%)$ & 0.7500 \\
\hline $\begin{array}{l}\text { ACC/AHA classification } \\
\text { Type B } 2 / C\end{array}$ & $939(82.9 \%)$ & $881(75.1 \%)$ & $<0.001$ \\
\hline \multicolumn{4}{|l|}{ Procedural characteristics } \\
\hline Total number of stents & $1.5 \pm 0.7$ & $1.3 \pm 0.6$ & $<0.0001$ \\
\hline $\begin{array}{l}\text { Average stent diameter } \\
(\mathrm{mm})\end{array}$ & $2.96 \pm 0.36$ & $2.98 \pm 0.36$ & 0.0911 \\
\hline Total length of stents (mm) & $31.7 \pm 18.4$ & $27.1 \pm 15.38$ & $<0.0001$ \\
\hline $\begin{array}{l}\text { Use of } 2.5 \mathrm{~mm} \text { diameter } \\
\text { stent }\end{array}$ & $429(37.9 \%)$ & $369(31.5 \%)$ & 0.0013 \\
\hline $\begin{array}{l}\text { Use of imaging device } \\
\text { for stent placement }\end{array}$ & $1071(94.5 \%)$ & $1099(93.8 \%)$ & 0.4394 \\
\hline
\end{tabular}

Variables are mean \pm SD or percentage. ACC: American College of Cardiology; AHA: American Heart Association.

$p=0.897)$. However, the cumulative incidence of ID-TLR was significantly lower in the $\beta$-blocker group (4.6\% vs. $6.8 \% ; p=0.047$ ) (Table III and Figure 1). The following variables had significant difference by univariate analysis for the effect on ID-TLR: diabetes mellitus (HR=2.73; $p=0.001)$, CKD (HR=2.94; $p=0.001)$, cardiogenic shock ( $\mathrm{HR}=4.07 ; p=0.049)$, left ventricular systemic dysfunction $(\mathrm{HR}=2.39 ; p=0.019)$, peripheral artery disease $(\mathrm{HR}=2.49$; $p<0.001)$, previous PCI $(\mathrm{HR}=1.46 ; p=0.049)$, multivessel disease $(\mathrm{HR}=1.75 ; p=0.003)$, use of $\beta$-blocker $(\mathrm{HR}=0.67$; $p=0.046)$, use of statin (HR=0.60; $p=0.024)$, ostial lesion $(\mathrm{HR}=1.87 ; p=0.010)$, restenosis lesion $(\mathrm{HR}=3.10 ; p<0.001)$, and severe calcified lesion $(\mathrm{HR}=2.07 ; p=0.001)$. Multivariate analysis using these variables demonstrated that $\beta$-blockers significantly reduced the risk of ID-TLR $(\mathrm{HR}=0.61 ; p=0.016)$ (Table IV).

\section{Discussion}

In our observational study of patients who had undergone EES, the $\beta$-blocker group had more comorbid risks, including hypertension, ACS, history of MI, and multivessel 


\begin{tabular}{|c|c|c|c|c|c|}
\hline & \multirow{2}{*}{$\begin{array}{l}\beta \text { Group } \\
(\mathrm{n}=918)\end{array}$} & \multirow{2}{*}{$\begin{array}{l}\text { Non- } \beta \text { group } \\
\quad(n=981)\end{array}$} & \multirow{2}{*}{$\begin{array}{c}\text { Log-rank } \\
p \text {-Value }\end{array}$} & \multicolumn{2}{|c|}{ Cox hazard model } \\
\hline & & & & Hazard ratio $[95 \% \mathrm{CI}]$ & $p$-Value \\
\hline All-cause deaths & $114(12.4 \%)$ & $132(13.5 \%)$ & 0.5858 & $0.932[0.725-1.198]$ & 0.5856 \\
\hline Cardiac death & $44(4.8 \%)$ & $59(6.0 \%)$ & 0.2659 & $0.802[0.540-1.812]$ & 0.2649 \\
\hline AMI & $31(3.4 \%)$ & $39(4.0 \%)$ & 0.5165 & $0.856[0.530-1.368]$ & 0.6644 \\
\hline Stent thrombosis & $28(3.1 \%)$ & $29(3.0 \%)$ & 0.8970 & $1.039[0.616-1.749]$ & 0.8864 \\
\hline Ischemia-driven TLR & $42(4.6 \%)$ & $66(6.8 \%)$ & 0.0475 & $0.678[0.457-0.994]$ & 0.0463 \\
\hline
\end{tabular}

Variables are shown as n (\%). AMI: Acute myocardial infarction; TLR: target lesion revascularization; CI: confidence interval.

disease compared to the non- $\beta$-blocker group; however, medications including statins, anticoagulants, ACEIs, and ARBs were more frequently used. In the $\beta$-blocker group, lesions that were difficult to treat (left main coronary artery and ostial lesions) were more frequent, and accordingly, the number and length of stents were greater than those in the non- $\beta$-blocker group. Nevertheless, outcomes, including allcause death, cardiac death, AMI, and ST were comparable to those of the non- $\beta$-blocker group and ID-TLR was lower in the $\beta$-blocker group. Among the factors associated with IDTLR via multivariate analysis, a prescription of $\beta$-blockers significantly reduced the risk of ID-TLR. These results may prompt the consideration of the administration of $\beta$-blockers after PCI in the second-generation DES era.

Previous in vitro studies have shown that $\beta$-blockers inhibit vascular smooth muscle cell (VSMC) proliferation and migration, as well as neointimal formation after vessel injury $(12,13)$. $\beta$-Blockers also have an antiplatelet effect that reduces platelet aggregation and deposition on the vessel wall (14-18); however, previous clinical studies from the 1990s had been inconsistent in demonstrating the benefits of $\beta$-blockers on restenosis rates. Johansson et al. compared 455 patients treated with $\beta$-blockers after percutaneous transluminal coronary angioplasty (PTCA) and 86 patients without $\beta$-blockers after PTCA and found no favorable effect on the restenosis rate. However, angiographic success was achieved in $78 \%$ of the patients (19). In a prospective, double-blind, randomized, placebo-controlled trial reported in the 2000 s, $\beta$-blockers were scheduled to be administered pre- and post-successful procedures, which were then compared to placebo groups. Even in this highly technical and well-scheduled cohort study, there was no difference found regarding the restenosis rate between $\beta$-blockers (carvedilol) versus placebo in patients undergoing directional coronary atherectomy (DCA) (20). In the 2010s, Jackson et al. showed that $\beta$-blockers reduced the six-month TLR in patients who underwent PCI $(7.8 \%$ in the $\beta$-blocker group vs. $10.2 \%$ in the without $\beta$-blocker group; odds ratio 0.75 , $p=0.006$ ) (11). The relatively higher TLR compared to our
Table IV. Multivariate analysis for ID-TLR.

\begin{tabular}{lrrr}
\hline & HR & $95 \%$ CI & $p$-Value \\
\hline Diabetes mellitus & 2.285 & $1.533-3.459$ & $<0.0001$ \\
Chronic kidney disease & 1.981 & $1.294-3.006$ & 0.0018 \\
Cardiogenic shock & 2.362 & $0.545-6.980$ & 0.2183 \\
Left ventricular & 1.792 & $0.835-3.436$ & 0.0126 \\
$\quad$ systolic dysfunction & 1.573 & $0.942-2.525$ & 0.0816 \\
Peripheral artery disease & 0.873 & $0.549-1.367$ & 0.5570 \\
Previous percutaneous & & & \\
coronary intervention & 1.659 & $1.126-2.458$ & 0.0105 \\
Multivessel disease & 0.613 & $0.406-0.916$ & 0.0166 \\
Use of $\beta$-blocker & 0.824 & $0.537-1.292$ & 0.3901 \\
Use of statin & 1.326 & $0.802-2.113$ & 0.2630 \\
Ostial lesion & 3.274 & $1.957-5.404$ & $<0.0001$ \\
Restenosis lesion & 1.423 & $0.918-2.168$ & 0.1127 \\
Severe calcified lesion & & & \\
\hline
\end{tabular}

ID-TLR: Ischemia-driven target lesion revascularization; HR: hazard ratio; CI: confidence interval.

study might be due to the lower frequency of stents (approximately 60\%) and the greater variety of procedures studied, such as angioplasty, DCA, and stent implantation in this study. The evolution of endovascular devices may also contribute to the improvement in TLR.

Intimal hyperplasia after stent implantation is caused primarily by VSMC proliferation and is regarded as the main factor for in-stent restenosis (21-23). In the 1990s, restenosis rates after BMS implantation was as high as $20 \%$ (1-3). DES, whose stent struts were coated with antiproliferative drugs, theoretically inhibited VSMC proliferation and prevented restenosis. The first-generation DES, sirolimus-eluting stents (SES), drastically reduced the rate of stent restenosis compared to BMS $(21,24)$. However, restenosis was not completely abolished, and intimal hyperplasia was still thought to cause a high restenosis rate clinically (25). Furthermore, despite the benefits of first-generation DES in reducing the risk of restenosis, two notable problems remain. Poor intimal coverage of stent struts due to too a strong inhibition of VSMC proliferation by long release agents (25) 
A All-cause deaths

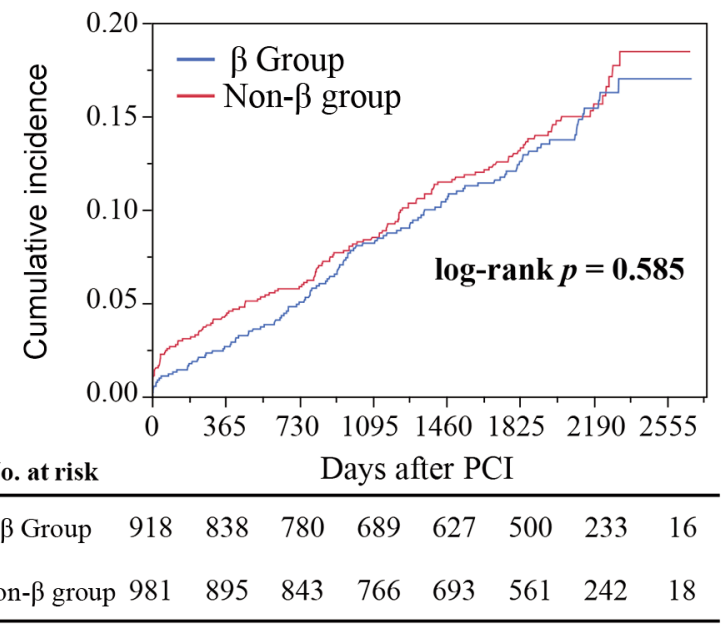

C Acute myocardial infarction

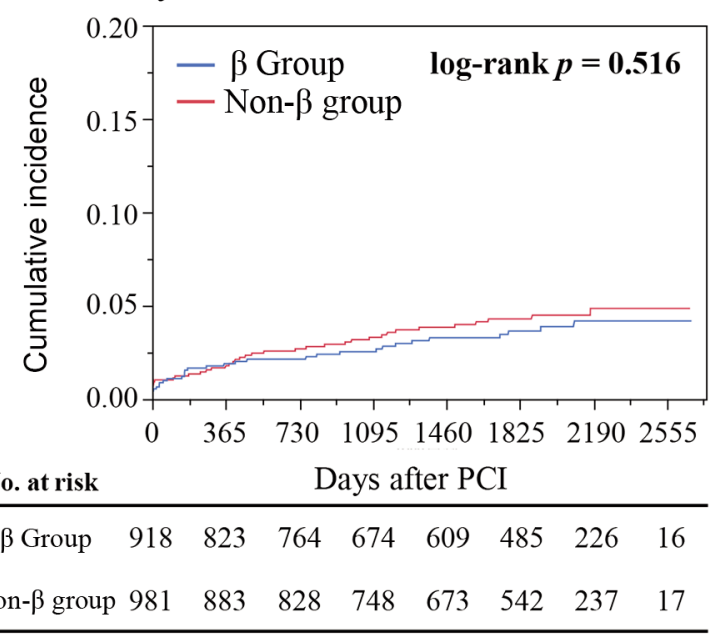

B Cardiac death

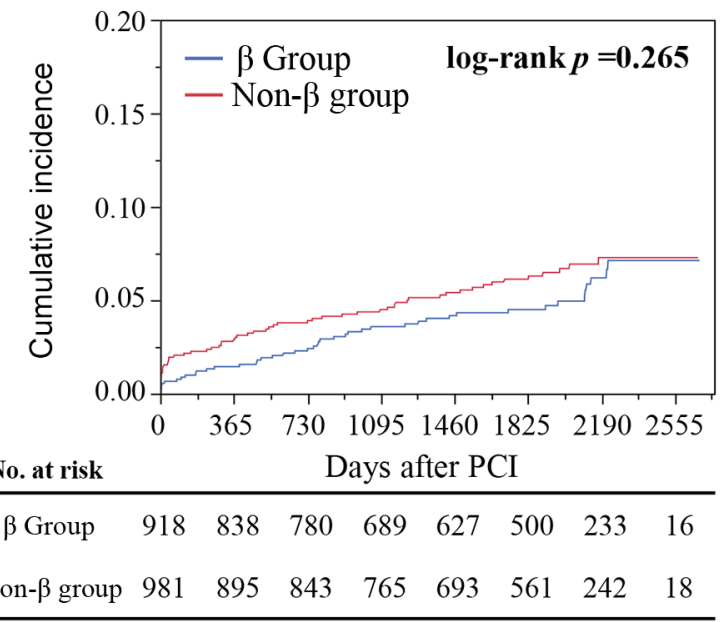

D Stent thrombosis

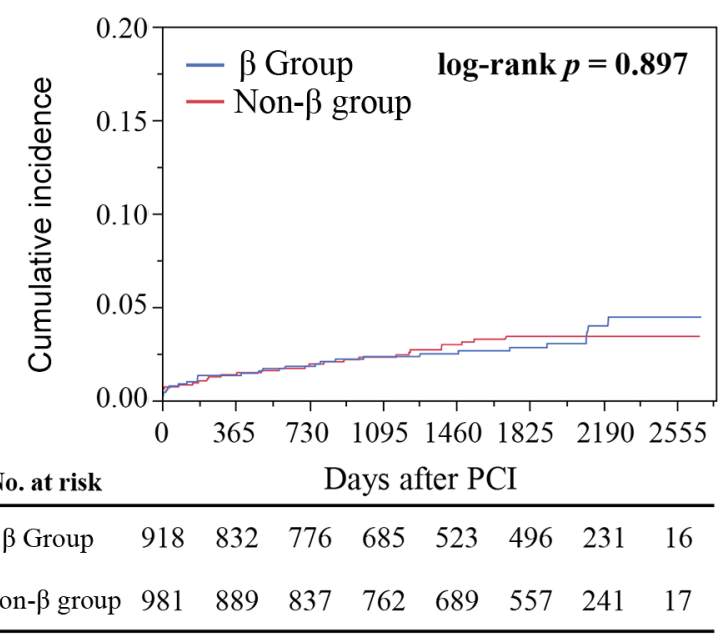

E Ischemia-driven target lesion revascularization

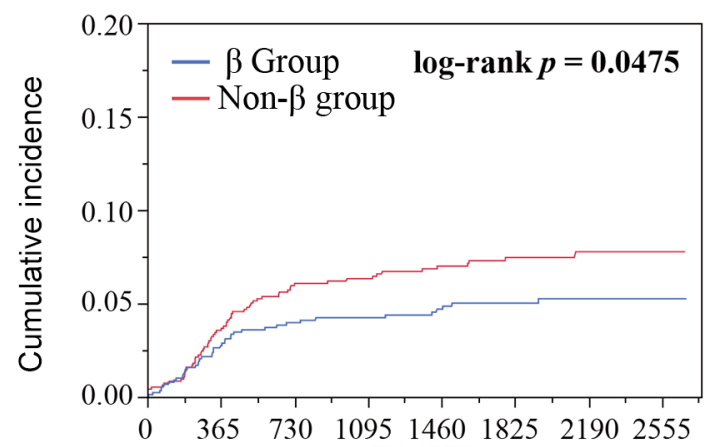

\begin{tabular}{cccccccccc} 
No. at risk & \multicolumn{7}{c}{ Days after PCI } \\
\hline$\beta$ Group & 918 & 845 & 709 & 664 & 603 & 477 & 311 & 16 \\
Non- $\beta$ group & 981 & 868 & 798 & 724 & 652 & 526 & 231 & 16 \\
\hline
\end{tabular}

Figure 1. Comparison of $(A)$ all-cause death $(B)$ cardiac death $(C)$ acute myocardial infarction $(D)$ stent thrombosis and $(E)$ ischemia-driven target lesion revascularization between the $\beta$-blocker group and the non- $\beta$-blocker group. 
and allergic inflammation against the polymers used in the first-generation DES both caused late stent restenosis (26). The second-generation DES was developed to overcome these problems and EES has successfully reduced the rate of ST and restenosis thanks to improved strut thickness, drug release durations, and biocompatible polymers $(5,6,27)$. de la Torre Hernández et al. have reported that the percentage of uncovered struts was only $0.8 \%$ at one-year follow-up by optical coherence tomography analyses (28). Furthermore, Otsuka et al., in their autopsy study, reported that significantly fewer uncovered struts were seen in patients with EES implantation compared to those using SES $(2.6 \%$ in EES $v s .18 .0 \%$ in SES, $p<0.001)$ and that less inflammation was seen in patients with EES, although $25 \%$ of patients with SES and $16 \%$ of patients with EES experienced stent-related deaths (29). One of the pleiotropic effects of $\beta$-blockers was improving the length of the anginafree exercise period, which might positively influence the outcomes of ID-TLR in our study.

In patients with SES after STEMI, Ozasa et al. reported that $\beta$-blockers were not able to reduce the three-year rate of TLR, neither in patients with low EF ( $\beta$-blocker group $17.7 \%$ vs. non- $\beta$-blocker group $22.2 \%, p=0.410$ ) nor in preserved EF patients (12.0\% vs. 12.2\%, $p=0.83$ ) (30). In our study, we set the EF threshold at 35\%. There were only 107 patients whose EF was less than $35 \%$. Therefore, we did not perform the subanalysis.

Based on this evidence, we assumed that the additional antiproliferative potential of $\beta$-blockers may affect outcomes, including TLR, on the condition that the stenotic lesion was fully intervened using recent technology. EES have thinner struts, more biocompatibility, and shorter drug release duration, all of which may lead to adequate intimal coverage, and thus, allow $\beta$-blockers to positively influence the sequence of neointimal formation, resulting in a reduction in ID-TLR in our study.

Recently DES-induced vasospastic angina has focused on as a novel complication, and $\beta$-blockers may promote "vasospasm" theoretically. However, the multicenter prospective randomized trial compared the effects of $\beta$ blockers and CCBs on coronary events after secondgeneration DES implantation revealed that the incidence of acetylcholine-induced coronary artery spasms did not differ between these groups at 9 months after PCI. In addition, the incidence of two year major adverse cardiovascular events (MACE) was lower in the $\beta$-blocker group (31). Among the factors comprising MACE, only the "coronary revascularization for stable CAD" was statistically significant, which might support our results of beneficial effect of $\beta$-blocker on ID-TLR.

Our study had some limitations. First, the Tokyo-MD PCI study was an observational, nonrandomized registry. For the current study, we excluded patients with missing data regarding $\beta$-blocker prescription, which amounted to $2 \%$ of the patients in the registry. Thus, selection bias may have influenced the results of this study. Second, although the coronary risk of the $\beta$-blocker group was higher, the medications including statins, anticoagulants, ACEIs, and ARBs being used by patients in this group benefitted them. Therefore, baseline comorbid risks of the $\beta$-blocker group should not be overemphasized. Third, we did not evaluate objective quantitative data from coronary arteriography or coronary imaging, and we used ID-TLR as a surrogate measure of restenosis. ID-TLR is not equivalent to restenosis; however, we assumed that the decision of additional intervention was a more objective and relevant endpoint to assess clinical effects than restenosis. Fourth, we did not study the types and dosages of $\beta$-blockers prescribed, mainly because of the multiple combinations possible. The types and doses of $\beta$-blockers might affect restenosis; however, the majority of $\beta$-blockers used for ischemic heart disease patients in this study were carvedilol and bisoprolol, likely reflecting general beta-blocker usage trends in Japan. Fifth, we analyzed only the patients with EES implantation to eliminate the influence of differences in stent types; therefore, the effect of $\beta$-blockers shown in our study cannot be extended to patients using other second-generation DES. Further studies are needed to determine the pharmacological mechanism by which $\beta$-blockers reduce ID-TLR after DES implantation.

In conclusion, we found that $\beta$-blocker administration reduced ID-TLR after PCI using an EES. Although the $\beta$ blocker group had more comorbid risks and more severe disease lesions, ID-TLR was less than that in the non- $\beta$ blocker group and the outcomes including mortality and stent coronary events were comparable.

\section{Conflicts of Interest}

The Authors have no association with industry that could constitute a conflict of interest.

\section{Authors' Contributions}

Conceptualization, T.F. and T.A.; methodology, T.A.; validation, K.H. and T.S.; formal analysis, T.A.; investigation, T.S.; data curation, T.S., K.K., S.Y. and H.I.; writing-original draft preparation, T.F.; writing - review and editing, K.H.; visualization, T.F.; supervision, T.S.; project administration, T.S. All Authors have read and agreed to the published version of the manuscript.

\section{Acknowledgements}

We thank the members of the cardiac catheterization laboratories of the participating centers. The list of participating investigators and centers is as follows:

Shigeo Shimizu, Daisuke Ueshima, Ome Municipal General Hospital, Hiroaki Yamaguchi, Okubo Hospital, Kazuo Kobayashi, 
Toru Miyazaki, Kashiwa Municipal Hospital, Akihiko Matsumura Kameda Medical Center, Yasuhiro Sato, National Disaster Medical Center, Junichi Nitta, Saitama Red Cross Hospital, Masahiko Furubayashi, Hidenobu Takei, Sanraku Hospital, Tsuyoshi Tokunaga, JA Toride Medical Center, Michio Usui, Social Insurance Chuo General Hospital, Ryo Goto, Shuuwa Medical Hospital, Hiroshi Inagaki, Soka Municipal Hospital, Tsunekazu Kakuta, Tsuchiura Kyodo General Hospital, Go Haraguchi, Yuji Konishi, Tokyo Medical and Dental University, Hiromasa Adachi, Tokyo Kyosai Hospital, Akihiro Hata, Toshima Hospital, Nobuhisa Obuchi, Tokyo Metropolitan Otsuka Hospital, Yuko Onishi, Hiratsuka Kyosai Hospital, Takanobu Miyamoto, Musashino Red Cross Hospital, Hiroyuki Hikita, Shigeki Kimura, Yokosuka Kyosai Hospital, Manabu Kurabayashi, Yokohama City Minato Red Cross Hospital, Hiroyuki Fujii, Yokohama Minami Kyosai Hospital, and Atsuyuki Ono, Otaki Yoichi, Kasai Shoikai Hospital.

\section{References}

1 Serruys PW, de Jaegere P, Kiemeneij F, Macaya C, Rutsch W, Heyndrickx G, Emanuelsson H, Marco J, Legrand V and Materne P: A comparison of balloon-expandable-stent implantation with balloon angioplasty in patients with coronary artery disease. Benestent Study Group. N Engl J Med 331(8): 489-495, 1994. PMID: 8041413. DOI: 10.1056/NEJM199408253310801

2 Fischman DL, Leon MB, Baim DS, Schatz RA, Savage MP, Penn I, Detre K, Veltri L, Ricci D and Nobuyoshi M: A randomized comparison of coronary-stent placement and balloon angioplasty in the treatment of coronary artery disease. Stent Restenosis Study Investigators. N Engl J Med 331(8): 496-501, 1994. PMID: 8041414. DOI: 10.1056/NEJM199408253310802

3 Kimura T, Yokoi H, Nakagawa Y, Tamura T, Kaburagi S, Sawada Y, Sato Y, Yokoi H, Hamasaki N and Nosaka H: Threeyear follow-up after implantation of metallic coronary-artery stents. N Engl J Med 334(9): 561-566, 1996. PMID: 8569823. DOI: $10.1056 /$ NEJM199602293340903

4 Moses JW, Leon MB, Popma JJ, Fitzgerald PJ, Holmes DR, O'Shaughnessy C, Caputo RP, Kereiakes DJ, Williams DO, Teirstein PS, Jaeger JL, Kuntz RE and SIRIUS Investigators: Sirolimus-eluting stents versus standard stents in patients with stenosis in a native coronary artery. N Engl J Med 349(14): 1315-1323, 2003. PMID: 14523139. DOI: 10.1056/ NEJMoa035071

5 Stone GW, Ellis SG, Cox DA, Hermiller J, O'Shaughnessy C, Mann JT, Turco M, Caputo R, Bergin P, Greenberg J, Popma JJ, Russell ME and TAXUS-IV Investigators: A polymer-based, paclitaxel-eluting stent in patients with coronary artery disease. N Engl J Med 350(3): 221-231, 2004. PMID: 14724301. DOI: 10.1056/NEJMoa032441

6 Stone GW, Rizvi A, Newman W, Mastali K, Wang JC, Caputo R, Doostzadeh J, Cao S, Simonton CA, Sudhir K, Lansky AJ, Cutlip DE, Kereiakes DJ and SPIRIT IV Investigators: Everolimus-eluting versus paclitaxel-eluting stents in coronary artery disease. N Engl J Med 362(18): 1663-1674, 2010. PMID: 20445180. DOI: 10.1056/NEJMoa0910496

7 Naidu SS, Krucoff MW, Rutledge DR, Mao VW, Zhao W, Zheng Q, Wilburn O, Sudhir K, Simonton C and Hermiller JB: Contemporary incidence and predictors of stent thrombosis and other major adverse cardiac events in the year after XIENCE V implantation: results from the 8,061-patient XIENCE V United States study. JACC Cardiovasc Interv 5(6): 626-635, 2012. PMID: 22721657. DOI: 10.1016/j.jcin.2012.02.014

8 Antman EM, Anbe DT, Armstrong PW, Bates ER, Green LA, Hand M, Hochman JS, Krumholz HM, Kushner FG, Lamas GA, Mullany CJ, Ornato JP, Pearle DL, Sloan MA, Smith SC Jr, Alpert JS, Anderson JL, Faxon DP, Fuster V, Gibbons RJ, Gregoratos G, Halperin JL, Hiratzka LF, Hunt SA, Jacobs AK and American College of Cardiology/American Heart Association Task Force on Practice Guidelines (Writing Committee to Revise the 1999 Guidelines for the Management of Patients With Acute Myocardial Infarction): ACC/AHA guidelines for the management of patients with ST-elevation myocardial infarction-executive summary: a report of the American College of Cardiology/American Heart Association Task Force on Practice Guidelines (Writing Committee to Revise the 1999 Guidelines for the Management of Patients With Acute Myocardial Infarction). Circulation 110(5): 588-636, 2004. PMID: 15289388. DOI: 10.1161/01.CIR.0000134791.68010.FA

9 Fraker TD Jr, Fihn SD, Gibbons RJ, Abrams J, Chatterjee K, Daley J, Deedwania PC, Douglas JS, Ferguson TB Jr, Fihn SD, Fraker TD Jr, Gardin JM, O'Rourke RA, Williams SV, Smith SC Jr, Jacobs AK, Adams CD, Anderson JL, Buller CE, Creager MA, Ettinger SM, Halperin JL, Hunt SA, Krumholz HM, Kushner FG, Lytle BW, Nishimura R, Page RL, Riegel B, Tarkington LG, Yancy $\mathrm{CW}$, American College of Cardiology, American Heart Association and American College of Cardiology/American Heart Association Task Force on Practice Guidelines Writing Group: 2007 chronic angina focused update of the ACC/AHA 2002 Guidelines for the management of patients with chronic stable angina: a report of the American College of Cardiology/American Heart Association Task Force on Practice Guidelines Writing Group to develop the focused update of the 2002 Guidelines for the management of patients with chronic stable angina. Circulation 116(23): 2762-2772, 2007. PMID: 17998462. DOI: 10.1161/CIRCULATIONAHA. 107.187930

10 Anderson JL, Adams CD, Antman EM, Bridges CR, Califf RM, Casey DE Jr, Chavey WE 2nd, Fesmire FM, Hochman JS, Levin TN, Lincoff AM, Peterson ED, Theroux P, Wenger NK, Wright RS, Smith SC Jr, 2011 WRITING GROUP MEMBERS and ACCF/AHA TASK FORCE MEMBERS: 2011 ACCF/AHA focused update incorporated into the ACC/AHA 2007 guidelines for the management of patients with unstable angina/non-STelevation myocardial infarction: a report of the American College of Cardiology Foundation/American Heart Association Task Force on Practice Guidelines. Circulation 123(18): e426-e579, 2011. PMID: 21444888. DOI: 10.1161/CIR.0b013e318212bb8b

11 Jackson JD, Muhlestein JB, Bunch TJ, Bair TL, Horne BD, Madsen TE, Lappé JM, Anderson JL and Intermountain Heart Collaborative Study Group: Beta-blockers reduce the incidence of clinical restenosis: prospective study of 4840 patients undergoing percutaneous coronary revascularization. Am Heart J 145(5): 875-881, 2003. PMID: 12766747. DOI: 10.1016/ S0002-8703(02)94726-5

12 Ohlstein EH, Douglas SA, Sung CP, Yue TL, Louden C, Arleth A, Poste G, Ruffolo RR Jr and Feuerstein GZ: Carvedilol, a cardiovascular drug, prevents vascular smooth muscle cell proliferation, migration, and neointimal formation following vascular injury. Proc Natl Acad Sci U.S.A. 90(13): 6189-6193, 1993. PMID: 8327499. DOI: 10.1073/pnas.90.13.6189 
13 Sung CP, Arleth AJ and Ohlstein EH: Carvedilol inhibits vascular smooth muscle cell proliferation. J Cardiovasc Pharmacol 21(2): 221-227, 1993. PMID: 7679155. DOI: 10.1097/00005344-199302000-00006

14 Kaplan JR, Pettersson K, Manuck SB and Olsson G: Role of sympathoadrenal medullary activation in the initiation and progression of atherosclerosis. Circulation 84(6 Suppl): VI23VI32, 1991. PMID: 1683607.

15 Winther K and Willich SN: Beta 1-blockade and acute coronary ischemia. Possible role of platelets. Circulation 84(6 Suppl): VI68-VI71, 1991. PMID: 1959217.

16 Hjemdahl P, Larsson PT and Wallén NH: Effects of stress and beta-blockade on platelet function. Circulation 84(6 Suppl): VI44-VI61, 1991. PMID: 1683610.

17 Campbell WB, Johnson AR, Callahan KS and Graham RM: Anti-platelet activity of beta-adrenergic antagonists: inhibition of thromboxane synthesis and platelet aggregation in patients receiving long-term propranolol treatment. Lancet 2(8260-61): 1382-1384, 1981. PMID: 6118758. DOI: 10.1016/s01406736(81)92800-2

18 Casscells W: Migration of smooth muscle and endothelial cells. Critical events in restenosis. Circulation 86(3): 723-729, 1992. PMID: 1516183. DOI: 10.1161/01.cir.86.3.723

19 Johansson SR, Lamm C, Bondjers G, Emanuelsson H and Hjalmarson A: Role of beta-adrenergic blockers after percutaneous transluminal coronary angioplasty. Am J Cardiol 66(12): 915-920, 1990. PMID: 1977297. DOI: 10.1016/00029149(90)90925-q

20 Serruys P, Foley D, Höfling B, Puel J, Glogar H, Seabra-gomes R, Goicolea J, Coste P, Rutsch W, Katus H, Bonnier H, Wijns W, Betriu A, Hauf-Zachariou U, van Swijndregt E, Melkert R and Simon R: Carvedilol for prevention of restenosis after directional coronary atherectomy. Circulation 101(13): 15121518, 2021. DOI: 10.1161/01.CIR.101.13.1512

21 Farb A, Weber DK, Kolodgie FD, Burke AP and Virmani R: Morphological predictors of restenosis after coronary stenting in humans. Circulation 105(25): 2974-2980, 2002. PMID: 12081990. DOI: 10.1161/01.cir.0000019071.72887.bd

22 Curcio A, Torella D and Indolfi C: Mechanisms of smooth muscle cell proliferation and endothelial regeneration after vascular injury and stenting: approach to therapy. Circ J 75(6): 1287-1296, 2011. PMID: 21532177. DOI: 10.1253/circj.cj-11-0366

23 Uchida Y, Uchida Y, Matsuyama A, Koga A, Kanai M and Sakurai T: Formation of web- and membrane-like structures on the edges of bare-metal coronary stents. Circ J 74(9): 1830-1836, 2010. PMID: 20622474. DOI: 10.1253/circj.cj-10-0093

24 Marks A: Sirolimus for the prevention of in-stent restenosis in a coronary artery. New England Journal of Medicine 349(14): 1307-1309, 2018. DOI: 10.1056/NEJMp038141

25 Stone GW, Moses JW, Ellis SG, Schofer J, Dawkins KD, Morice MC, Colombo A, Schampaert E, Grube E, Kirtane AJ, Cutlip DE, Fahy M, Pocock SJ, Mehran R and Leon MB: Safety and efficacy of sirolimus- and paclitaxel-eluting coronary stents. N Engl J Med 356(10): 998-1008, 2007. PMID: 17296824. DOI: 10.1056/NEJMoa067193
26 Virmani R, Guagliumi G, Farb A, Musumeci G, Grieco N, Motta T, Mihalcsik L, Tespili M, Valsecchi O and Kolodgie FD: Localized hypersensitivity and late coronary thrombosis secondary to a sirolimus-eluting stent: should we be cautious? Circulation 109(6): 701-705, 2004. PMID: 14744976. DOI: 10.1161/01.CIR.0000116202.41966.D4

27 Baber U, Mehran R, Sharma SK, Brar S, Yu J, Suh JW, Kim HS, Park SJ, Kastrati A, de Waha A, Krishnan P, Moreno P, Sweeny J, Kim MC, Suleman J, Pyo R, Wiley J, Kovacic J, Kini AS and Dangas GD: Impact of the everolimus-eluting stent on stent thrombosis: a meta-analysis of 13 randomized trials. J Am Coll Cardiol 58(15): 1569-1577, 2011. PMID: 21924575. DOI: 10.1016/j.jacc.2011.06.049

28 de la Torre Hernández JM, Lee DH, Garcia-Camarero T, Sainz Laso $\mathrm{F}$ and Zueco J: Comparison of paclitaxel-eluting vs. everolimus-eluting stents implanted simultaneously in different lesions of the same coronary artery: 12-month follow-up with optical coherence tomography. EuroIntervention 9(8): 952-958, 2013. PMID: 24384292. DOI: 10.4244/EIJV9I8A159

29 Otsuka F, Vorpahl M, Nakano M, Foerst J, Newell JB, Sakakura K, Kutys R, Ladich E, Finn AV, Kolodgie FD and Virmani R: Pathology of second-generation everolimus-eluting stents versus first-generation sirolimus- and paclitaxel-eluting stents in humans. Circulation 129(2): 211-223, 2014. PMID: 24163064. DOI: $10.1161 /$ CIRCULATIONAHA.113.001790

30 Ozasa N, Kimura T, Morimoto T, Hou H, Tamura T, Shizuta S, Nakagawa Y, Furukawa Y, Hayashi Y, Nakao K, Matsuzaki M, Nobuyoshi M, Mitsudo K and j-Cypher Registry Investigators: Lack of effect of oral beta-blocker therapy at discharge on longterm clinical outcomes of ST-segment elevation acute myocardial infarction after primary percutaneous coronary intervention. Am J Cardiol 106(9): 1225-1233, 2010. PMID: 21029817. DOI: 10.1016/j.amjcard.2010.06.048

31 Sawano M, Katsuki T, Kitai T, Tamita K, Obunai K, Ikegami Y, Yamane T, Ueda I, Endo A, Maekawa Y, Kawamura A, Fukuda $\mathrm{K}$ and Kohsaka S: Beta blockers versus calcium channel blockers for provocation of vasospastic angina after drug-eluting stent implantation: a multicentre prospective randomised trial. Open Heart 7(2): e001406, 2020. PMID: 33087441. DOI: 10.1136/openhrt-2020-001406
Received October 13, 2021

Revised November 8, 2021 Accepted November 17, 2021 